\title{
Effect of bismuth subcitrate and sucralfate on rat duodenal and human gastric bicarbonate secretion in vivo
}

\author{
C J Shorrock, A Garner, A H Hunter, J R Crampton, W D W Rees
}

\begin{abstract}
Acid and alkali secretion have been examined together with prostaglandin $\mathbf{E}_{2}$ production in response to two mucosal protective drugs, colloidal bismuth subcitrate and sucralfate. Doses of colloidal bismuth subcitrate in the therapeutic range (120 and $1200 \mathrm{mg}$ ) had no effect on alkali secretion or luminal $\mathrm{PGE}_{2}$ output when perfused into the stomach of human volunteers. Similarly, in the anaesthetised rat, neither gastric acid nor duodenal alkali secretions were influenced by iv (12 mg/ $\mathrm{kg}$ ) or topical $(120 \mathrm{mg} / \mathrm{ml})$ administration of colloidal bismuth subcitrate. In contrast, perfusion of the human stomach with $1 \mathrm{~g}$ sucralfate stimulated bicarbonate output by $50 \%$, a response which was unaffected by indomethacin $(25 \mathrm{mg} / \mathrm{h})$. A rise of $64 \%$ in gastric $\mathrm{PGE}_{2}$ output after sucralfate was, however, prevented by indomethacin pretreatment. Alkali secretion by rat duodenum was also increased by sucralfate but the response depended on the basal secretory rate. Low basal secretors $(<3 \mu \mathrm{mol})$ showed a $75 \%$ stimulation whereas rats with high basal secretory rates ( $>3 \mu \mathrm{mol}$ ) showed no significant response. All duodenal preparations regardless of basal secretory rate showed a stimulation of bicarbonate output with topical $\mathrm{PGE}_{2}$. The results suggest that enhancement of gastroduodenal bicarbonate secretion may play a role in the protective action of sucralfate but is unlikely to explain mucosal protection by colloidal bismuth subcitrate.
\end{abstract}

Sucralfate and colloidal bismuth subcitrate (CBS) have both been shown to protect gastroduodenal mucosa against experimental damage $^{1-3}$ and to heal peptic ulcers in man. ${ }^{+7}$ Neither agent effects acid secretion ${ }^{89}$ and their mechanisms of ulcer healing and mucosal protection remain unclear.

Sucralfate, a basic aluminium salt of sucrose octasulphate, was originally proposed to act by adhering to damaged and ulcerated tissue thereby forming a physical barrier against injury by luminal acid, pepsin and bile salts. ${ }^{10-12}$ More recent studies indicate that this drug has additional actions on gastroduodenal mucosa which may contribute to its protective effect. For example, sucralfate has been reported to stimulate prostaglandin generation, ${ }^{13}$ bicarbonate secretion, ${ }^{14}$ and mucus production ${ }^{15}$ in laboratory animals.

Colloidal bismuth subcitrate precipitates in the acidic environment of the stomach which would encourage binding to the mucosal surface in a similar manner to sucralfate. In addition to the formation of a physical barrier, this adherence could also initiate an irritant reaction which would lead to the reported formation and release of endogenous prostaglandins. ${ }^{16}{ }^{17}$ Clinical interest in colloidal bismuth subcitrate $\left(\mathrm{De}-\mathrm{Nol}^{\circledR}\right.$, Gist-Brocades) has recently been aroused by reports of lowered duodenal ulcer relapse rates in comparison with $\mathrm{H}_{2}$ receptor antagonists. ${ }^{18-20}$ The reasons for this are unclear although the bactericidal action of bismuth against Campylobacter pylori is the currently favoured hypothesis. ${ }^{21}$

The present studies were designed to evaluate the actions of sucralfate and colloidal bismuth subcitrate on mucosal bicarbonate secretion in the rat duodenum and human stomach.

\section{Methods}

ANIMALS

Experiments were performed using female Sprague-Dawley rats (200-220 g body weight) obtained from ICI Pharmaceuticals animal breeding unit. Rats were starved for 20-24 hours before use in cages with wide mesh bottoms to prevent coprophagy but allowed free access to drinking water.

\section{Measurement of secretion}

Duodenal bicarbonate secretion was measured as previously described. ${ }^{22}$ Briefly, animals were anaesthetised with urethane $1.5 \mathrm{~g} / \mathrm{kg} \mathrm{im}$. Body temperature was maintained at $37^{\circ} \mathrm{C}$ by means of a heated table and intrarectal thermistor. A 12 $\mathrm{mm}$ segment of the descending part of the duodenum, starting $5 \mathrm{~mm}$ distal to the outlet of the bile duct and about $2 \mathrm{~cm}$ from the pylorus, was cannulated in situ. The bile duct and pylorus were ligated. A femoral vein was cannulated to enable infusion of saline $(1 \mathrm{ml} / \mathrm{kg} / \mathrm{h})$ to prevent dehydration and for administration of drugs. The duodenal segment was perfused with $4 \mathrm{ml}$ of $0.15 \mathrm{M} \mathrm{NaCl}$ at $37^{\circ} \mathrm{C}$ which was circulated rapidly by a gas lift of $100 \%$ oxygen prewashed in $\mathrm{Ba}(\mathrm{OH})_{2}$. The rate of alkalinisation was determined by continuous titration to $\mathrm{pH} 7 \cdot 4$ with $25 \mathrm{mM} \mathrm{HCl}$ made isotonic with $\mathrm{NaCl}$. Titrant delivery was controlled automatically using standard pH-stat equipment (GK 2321C pH electrode, ABU 80, PHM 62, TTT 80, all Radiometer Copenhagen, Denmark).

For measurement of acid secretion, the stomach was perfused at $7 \mathrm{ml} / \mathrm{min}$ with saline through the oesophagus and fluid collected by an outlet tube in the pylorus. Secretion was 
stimulated with the $\mathrm{H}_{2}$ agonist dimaprit $(\mathrm{SK} \& \mathrm{~F}$, Welwyn, UK) given as a $10 \mathrm{mg} / \mathrm{kg}$ bolus and $30 \mathrm{mg} / \mathrm{kg} / \mathrm{h}$ sc infusion. Acid output was determined every $10 \mathrm{~min}$ for a total of two hours by titration of samples with $20 \mathrm{mM} \mathrm{NaOH}$ to pH 6.4.

\section{Experimental design}

After completion of surgery, the preparation was allowed to stabilise for about one hour. Alkalinisation $(\mu \mathrm{mol} / \mathrm{cm} / \mathrm{h})$ was determined at 15 minute intervals and mean rates of secretion (SEM) compared before and after drug treatment by paired $t$ test.

Basal alkali secretion was measured for 60 minutes then either sucralfate or bismuth subcitrate added to the luminal solution in $100 \mu \mathrm{l}$ volumes to give a final concentration of $1 \mathrm{mg} / \mathrm{ml}$ for sucralfate and 11.7 or $117 \mathrm{mg} / \mathrm{ml}$ (10 and $100 \mu \mathrm{mol}$ ) for bismuth subcitrate. The effects of iv administration of colloidal bismuth subcitrate $(11.7$ and $117 \mathrm{mg} / \mathrm{kg})$ were also determined in a separate series of experiments. In the case of sucralfate, drug addition induced transient fluctuations in the $\mathrm{pH}$ of the luminal perfusate. A 20 minute re-equilibration period was therefore allowed after drug addition before recommending measurement of alkali secretion for a further $60 \mathrm{~min}$. The viability and sensitivity of individual preparations was assessed at the end of each experiment by recording maximal secretory response $45 \mathrm{~min}$ after adding $10 \mu \mathrm{g} / \mathrm{ml}$ prostaglandin $\mathrm{E}_{2}\left(\mathrm{PGE}_{2}\right)$ to the luminal solution.

\section{Drugs}

Sucralfate was obtained as an amorphous powder (Ayerst Laboratories, Andover, UK) and formulated as a saline suspension. Addition of $100 \mu \mathrm{l}$ to the luminal solution was equivalent to adding $1 \mathrm{mg} / \mathrm{ml}$ of the aluminium salt of sucrose octasulphate.

Bismuth subcitrate was also obtained as an amorphous powder (Gist-Brocades, Delft, The Netherlands) and prepared as a concentrated solution in saline at room temperature so that addition of $100 \mu \mathrm{l}$ produced a final concentration of $117 \mathrm{mg} / \mathrm{ml}$.

$\mathrm{PGE}_{2}$ (Sigma Chemicals, St Louis, MO) was dissolved in ethanol, stored at $-20^{\circ} \mathrm{C}$ and added to the luminal solution in a volume of $30 \mu \mathrm{l}$ to produce a final concentration of $10 \mu \mathrm{g} / \mathrm{ml}$.

\section{HUMAN STUDIES}

\section{Subjects}

Studies were performed in 20 male and six female healthy volunteers aged between 18 and 27 years who were taking no medication. Four groups of subjects received either 1 or $10 \mathrm{mg} / \mathrm{ml}$ bismuth subcitrate (both $\mathrm{n}=6$ ), $8 \mathrm{mg} / \mathrm{ml}$ sucralfate $(\mathrm{n}=8)$, or sucralfate plus $0.21 \mathrm{mg} / \mathrm{ml}$ indomethacin $(n=6)$.

\section{Measurement of secretion}

Gastric bicarbonate secretion by the intact human stomach was measured by an intubation method described previously. ${ }^{23}$ After an overnight fast the volunteers swallowed a multilumen polyethylene tube which was positioned by fluoroscopy with its tip in the second or third part of the duodenum. Ranitidine ( $150 \mathrm{mg}$ orally one hour beforehand and $25 \mathrm{mg} / \mathrm{h}$ iv during the study) was given to maintain intragastric $\mathrm{pH}$ between 6 and 7. Saliva was continuously removed by suction which reduced salivary contamination to below 3\% of measured gastric bicarbonate. After aspiration of resting gastric contents, the stomach and duodenum were perfused at $2 \mathrm{ml} / \mathrm{min}$ with saline containing 12.5 $\mu \mathrm{Ci} / \mathrm{l}$ of ${ }^{3} \mathrm{H}$-polyethylene glycol and ${ }^{14} \mathrm{C}$-polyethylene glycol respectively. Aspirates were collected by continuous suction at 10 minute intervals from the antrum and duodenum for measurement of marker concentration. Aliquots (1 $\mathrm{ml}$ ) were frozen for later assay of $\mathrm{PGE}_{2}$ concentration. In the middle of each sampling period a separate $1 \mathrm{ml}$ aliquot was aspirated into a cooled syringe for immediate determination of $\mathrm{pH}$ and $\mathrm{pCO}_{2}$.

\section{Analytical methods}

Concentrations of ${ }^{3} \mathrm{H}-\mathrm{PEG}$ and ${ }^{14} \mathrm{C}-\mathrm{PEG}$ in the samples were measured by liquid scintillation counting (LKB Wallace 2000 Beta Counter) with external quench correction. The $\mathrm{pH}$ and $\mathrm{pCO}_{2}$ of the samples were measured using a Corning 170 Blood Gas Analyser. Prostaglandin $\mathrm{E}_{2}$ concentrations were measured by radioimmunoassay after extraction into $2 \mathrm{ml}$ diethyl ether, evaporation then resuspension into $1 \mathrm{ml}$ radioimmunoassay buffer. Recovery experiments revealed a good correlation between amounts of $\mathrm{PGE}_{2}$ added and measured (102 (15)\% of that added, mean ( $\mathrm{SD}), \mathrm{n}=8$ ) suggesting low cross-reactivity with potential interfering substances.

\section{Experimental design}

After an equilibration period of one hour, basal bicarbonate secretion was measured for 60 minutes. The gastric perfusate was then changed to ${ }^{3} \mathrm{H}$-PEG containing either sucralfate in suspension $(8 \mathrm{mg} / \mathrm{ml})$ or a bismuth subcitrate solution $(1$ or $10 \mathrm{mg} / \mathrm{ml})$ and perfusion continued for a further hour. Total amounts perfused were equivalent to $1 \mathrm{~g}$ sucralfate and either 120 or 1200 mg bismuth subcitrate. In the third hour there was a return to the original perfusate.

To study the effects of cyclooxygenase inhibition on the response to sucralfate, the gastric perfusate was changed to ${ }^{3} \mathrm{H}-\mathrm{PEG}$ containing indomethacin $(0.21 \mathrm{mg} / \mathrm{ml})$ halfway through the first basal period. After $30 \mathrm{~min}$ the gastric perfusate was again changed to ${ }^{3} \mathrm{H}-\mathrm{PEG}$ containing indomethacin $(0.21 \mathrm{mg} / \mathrm{ml})$ plus sucralfate $(8$ $\mathrm{mg} / \mathrm{ml}$ ) for a further hour before returning to the original perfusate ( ${ }^{3} \mathrm{H}-\mathrm{PEG}$ alone) in the third hour.

\section{Drugs}

Bismuth subcitrate was obtained as an amorphous powder and made up as a solution in ${ }^{3} \mathrm{H}-\mathrm{PEG}$ to give a final concentration of either 1 $\mathrm{mg} / \mathrm{ml}$ or $10 \mathrm{mg} / \mathrm{ml}$. Although colloidal bismuth 


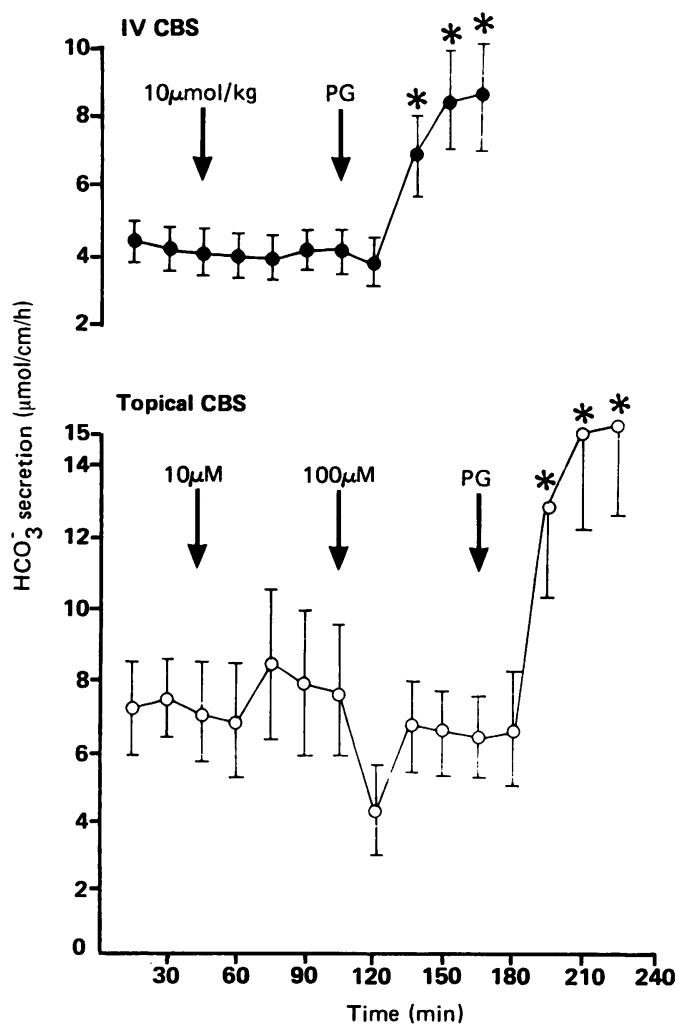

Figure 1: Effect of topical and iv colloidal bismuth subcitrate on rat duodenal alkali secretion. The alkali response to topical $P G E_{2}(10 \mu \mathrm{g} / \mathrm{ml})$ is also shown $(\mathrm{O}=$ topical colloidal bismuth subcitrate, mean $(S E), n=5,{ }^{\star} p<0.01 ; O=i v$ colloidal bismuth subcitrate, $n=6,{ }^{\star} p<0 \cdot 01$ ).

subcitrate possesses little buffering capacity, the suspension was titrated to $\mathrm{pH} 7 \cdot 4$ before administration.

Sucralfate was obtained in suspension and diluted to produce a concentration of $8 \mathrm{mg} / \mathrm{ml}$. This formulation was also titrated to $\mathrm{pH} 7 \cdot 4$ before use.

Indomethacin (Sigma Chemicals, Poole, UK) was prepared as an aqueous solution of concentration $0.21 \mathrm{mg} / \mathrm{ml}$ at $\mathrm{pH} 7 \cdot 4$.

\section{Calculation of results}

Gastric and duodenal volumes were calculated from marker dilution and perfusion rate. Duodenogastric reflux was calculated from the amount of ${ }^{14} \mathrm{C}$-PEG appearing in the gastric aspirate. Free bicarbonate concentration was calculated using the Henderson-Hasselbach equation and was added to that bicarbonate in the form of $\mathrm{CO}_{2}\left(\mathrm{pCO}_{2} \times\right.$ solubility constant of 0.031 ) in order to determine total bicarbonate concentration. Output was calculated as the product of volume and concentration corrected for refluxed bicarbonate. Similarly, prostaglan$\operatorname{din} E_{2}$ output was the product of concentration and volume. All results are expressed as means (SEM) and differences assessed by paired $t$ test.

\section{Results}

\section{ANIMAL STUDIES}

\section{Bismuth subcitrate}

Topical application of 10 and $100 \mu \mathrm{mol}$ colloidal bismuth subcitrate had no effect on alkali secre- tion by rat distal duodenum (Fig 1). The preparation responded to topical $\mathrm{PGE}_{2}(10 \mu \mathrm{g} / \mathrm{ml})$ which induced a peak stimulation of $110 \%$ from $6.60(1.65)$ to $15.4(2.63) \mu \mathrm{mol} / \mathrm{cm} / \mathrm{h}(\mathrm{p}<0.01$, $\mathrm{n}=5)$

Similarly, intravenous administration of 10 $\mu \mathrm{mol} / \mathrm{kg}$ had no effect on alkalinisation while topical $\mathrm{PGE}_{2}(10 \mu \mathrm{g} / \mathrm{ml})$ increased secretory rate by $120 \%$ from $4.30(0.60)$ to $9.0(1.56) \mu \mathrm{mol} / \mathrm{cm} /$ $\mathrm{h}(\mathrm{p}<0.01, \mathrm{n}=6)$ (Fig 1). This dose of colloidal bismuth subcitrate was without effect on dimaprit stimulated gastric acid secretion in the rat over a two hour period (acid secretion $=174$ (14) $\mu \mathrm{mol}$ in controls and 182 (19) $\mu \mathrm{mol}$ in treated animals, $\mathrm{p}>0 \cdot 1, \mathrm{n}=10$ ). When the higher dose of colloidal bismuth subcitrate $(100 \mu \mathrm{mol} / \mathrm{kg}$ $(117 \mathrm{~g} / \mathrm{kg}))$ was administered systemically, all the animals died.

\section{Sucralfate}

Sucralfate induced two distinct responses depending upon basal secretory rate. Topical application of sucralfate $1 \mathrm{mg} / \mathrm{kg}$ to rats with high rates of basal alkali secretion $(>3 \mu \mathrm{mol} / \mathrm{cm} / \mathrm{h}$, $n=4)$ had no effect on alkali secretion. Thus secretory rate during drug exposure $(5 \cdot 45(1 \cdot 30)$ $\mu \mathrm{mol} / \mathrm{cm} / \mathrm{h}$ ) was similar to that during the basal period $(5.55(1.36))$ although $\mathrm{PGE}_{2}(10 \mu \mathrm{g} / \mathrm{ml})$ stimulated secretion by $90 \%$ from $4.90(1 \cdot 17)$ to $9.30(1.31) \mu \mathrm{mol} / \mathrm{cm} / \mathrm{h}, \mathrm{p}<0.05$ (Fig 2).

In the animals with low basal alkali secretion ( $<3 \mu \mathrm{mol} / \mathrm{cm} / \mathrm{h}, \mathrm{n}=4$ ) topical sucralfate produced a rise in alkali secretion of $175 \%$ from $1 \cdot 20$ $(0.33)$ to $3.3(0.97) \mu \mathrm{mol} / \mathrm{cm} / \mathrm{h}, \mathrm{p}<0.05$. These preparations appeared more sensitive to $\mathrm{PGE}_{2}$ which increased secretory rate by $460 \%$ over the initial basal value (from $1.20(0.33)$ to $7 \cdot 0(1 \cdot 85)$ $\mu \mathrm{mol} / \mathrm{cm} / \mathrm{h}, \mathrm{p}<0.05)$.

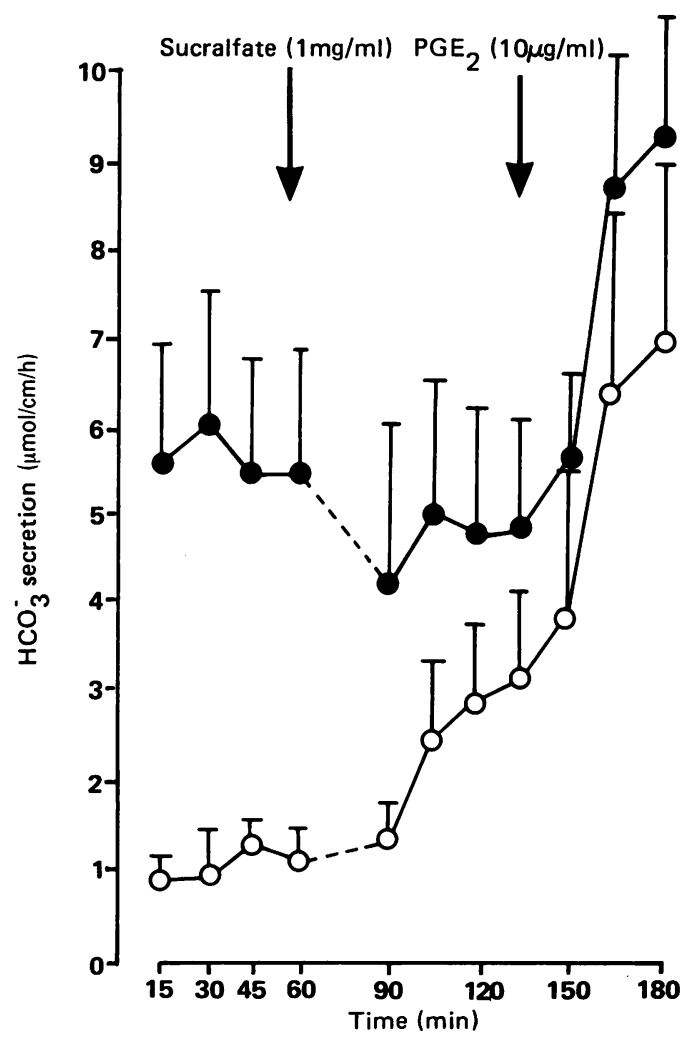

Figure 2: Effect of topical sucralfate and $P G E_{2}$ on rat duodenal alkali secretion in high $(\boldsymbol{O})$ and low $(\bigcirc)$ basal secretors (mean $(S E), n=4$ for both groups). 

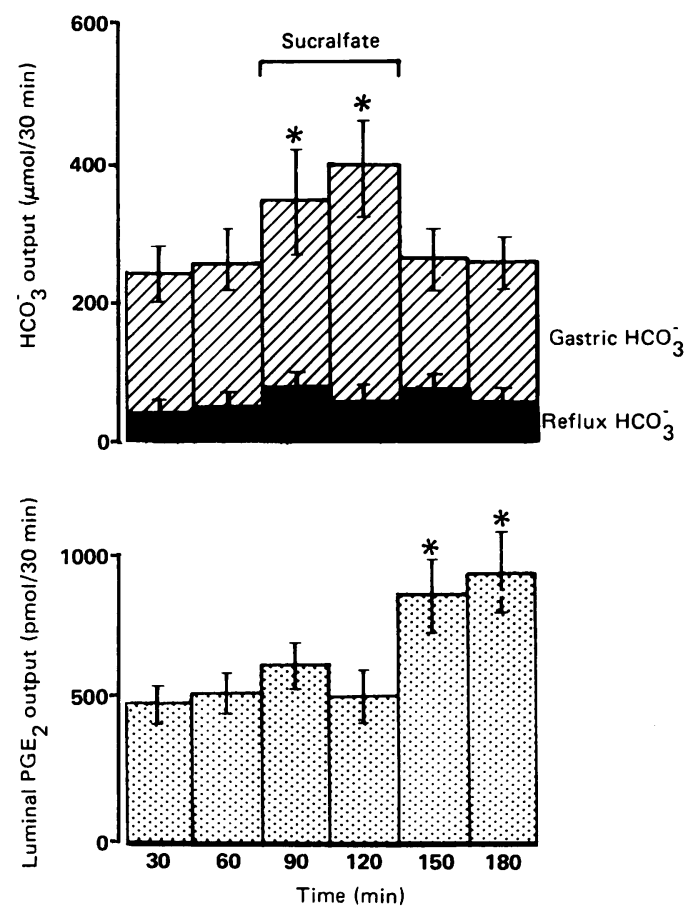

Figure 3: Effect of sucralfate ( $1 \mathrm{~g}$ ) on human gastric bicarbonate and luminal $P G E_{2}$ outputs (mean $(S E), n=8$, $\left.{ }^{\star} p<0 \cdot 01\right)$.

\section{HUMAN STUDIES}

Bismuth subcitrate

Neither concentration of bismuth subcitrate influenced alkali secretion of luminal $\mathrm{PGE}_{2}$ output by the human stomach (Table).

\section{Sucralfate}

During perfusion of the stomach with $1 \mathrm{~g}$ sucralfate over one hour there was a significant increase in alkali secretion from 494 (74) to 741 (88) $\mu \mathrm{mol} / \mathrm{h}(\mathrm{n}=8, \mathrm{p}<0.01)$ which returned towards basal values when the drug containing suspension was replaced by PEG during the third hour (Fig 3). There was no change in bicarbonate originating from duodenogastric reflux during the three study periods. There was no significant change in $\mathrm{PGE}_{2}$ output when the basal period (1099 (103) pmol/h) and sucralfate perfusion period $(1136(121) \mathrm{pmol} / \mathrm{h})$ were compared $(p>0 \cdot 1)$. However a significant rise $(p<0.05)$ in $\mathrm{PGE}_{2}$ output was recorded during the final hour (1799 (205)). The stimulation in bicarbonate output induced by sucralfate was due to an increase in gastric fluid secretion with the volume rising from $66(15)$ to $135(33) \mathrm{ml} / \mathrm{h}$ during drug perfusion (Fig 4). There was no significant increase in bicarbonate concentration during exposure to sucralfate $(3.09(0.22)$ and $3.40(0.27) \mathrm{mmol} / \mathrm{l}, \mathrm{p}>0.1)$. The increase in

TABLE Gastric bicarbonate ( $\mu \mathrm{mol} / \mathrm{h}$ ) and luminal $P G E_{2}$ (pmol/h) outputs during perfusion of the human stomach with either 1 or $10 \mathrm{mg} / \mathrm{ml}$ colloidal bismuth subcitrate (mean $(S E)$ $n=6$ for each concentration). Colloidal bismuth subcitrate was perfused during the second hour only

\begin{tabular}{llllr}
\hline Concentration & Output & 1st hour & 2nd hour & 3rd hour \\
\hline $1 \mathrm{mg} / \mathrm{ml}$ & $\mathrm{HCO}_{3}^{-}$ & $593(118)$ & $611(163)$ & $631(124)$ \\
& $\mathrm{PGE}_{2}$ & $1005(130)$ & $1210(165)$ & $1106(163)$ \\
$10 \mathrm{mg} / \mathrm{ml}$ & $\mathrm{HCO}_{3}^{-}$ & $453(114)$ & $412(86)$ & $489(108)$ \\
& $\mathrm{PGE}_{2}$ & $898(126)$ & $998(110)$ & $1060(134)$ \\
\hline
\end{tabular}

$\mathrm{PGE}_{2}$ output, however, was not a result of the increase in fluid secretion since the $\mathrm{PGE}_{2}$ and volume response were clearly dissociated.

\section{Indomethacin and sucralfate}

Perfusion of the stomach with indomethacin alone ( $12.5 \mathrm{mg}$ over 30 minutes) produced a fall in basal alkali secretion, although this reduction did not achieve statistical significance (696 (160) $\mu \mathrm{mol} / \mathrm{h}$ basally and 384 (93) during indomethacin perfusion, $n=6, p=0.058)$. A higher dose of indomethacin $(25 \mathrm{mg})$ caused a similar, insignificant reduction in alkali output and had no influence on the stimulation of alkali secretion induced by $1 \mathrm{~g}$ sucralfate which increased from $384(93) \mu \mathrm{mol} / \mathrm{h}$ to $782(132) \mu \mathrm{mol} / \mathrm{h}(\mathrm{p}<0.05)$ and then returned to basal values during the final hour (Fig 5).

Luminal $\mathrm{PGE}_{2}$ output was lower during the period of indomethacin perfusion alone but this reduction failed to reach statistical significance $(p=0.068)$. No further change in $\mathrm{PGE}_{2}$ output occurred during or after perfusion of the stomach with indomethacin plus sucralfate (Fig 5 ), in contrast with the rise in luminal $\mathrm{PGE}_{2}$ output observed during this final hour with sucralfate alone (Fig 3)

\section{Discussion}

Our results show quite different effects for two commonly used mucosal protective and ulcer healing agents. In the case of colloidal bismuth subcitrate we have been unable to show any effects on human gastric and rat duodenal bi-
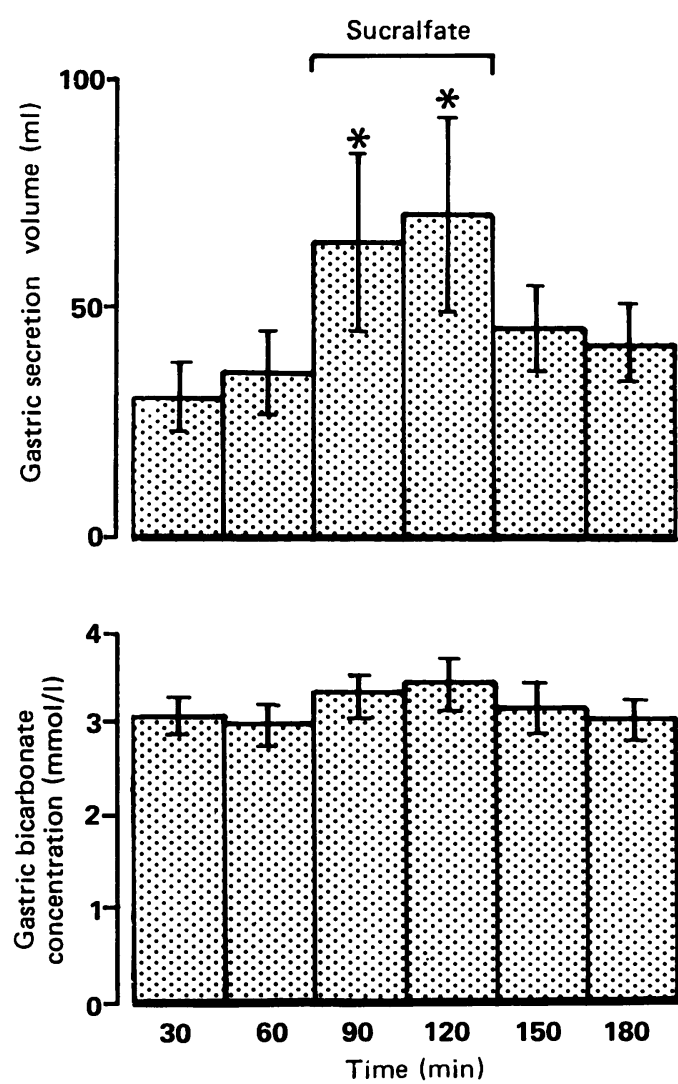

Figure 4: Effect of sucralfate on human gastric secretory volume and bicarbonate concentration (mean (SE), $n=8$, ${ }^{\star} p<0.05$ ). 

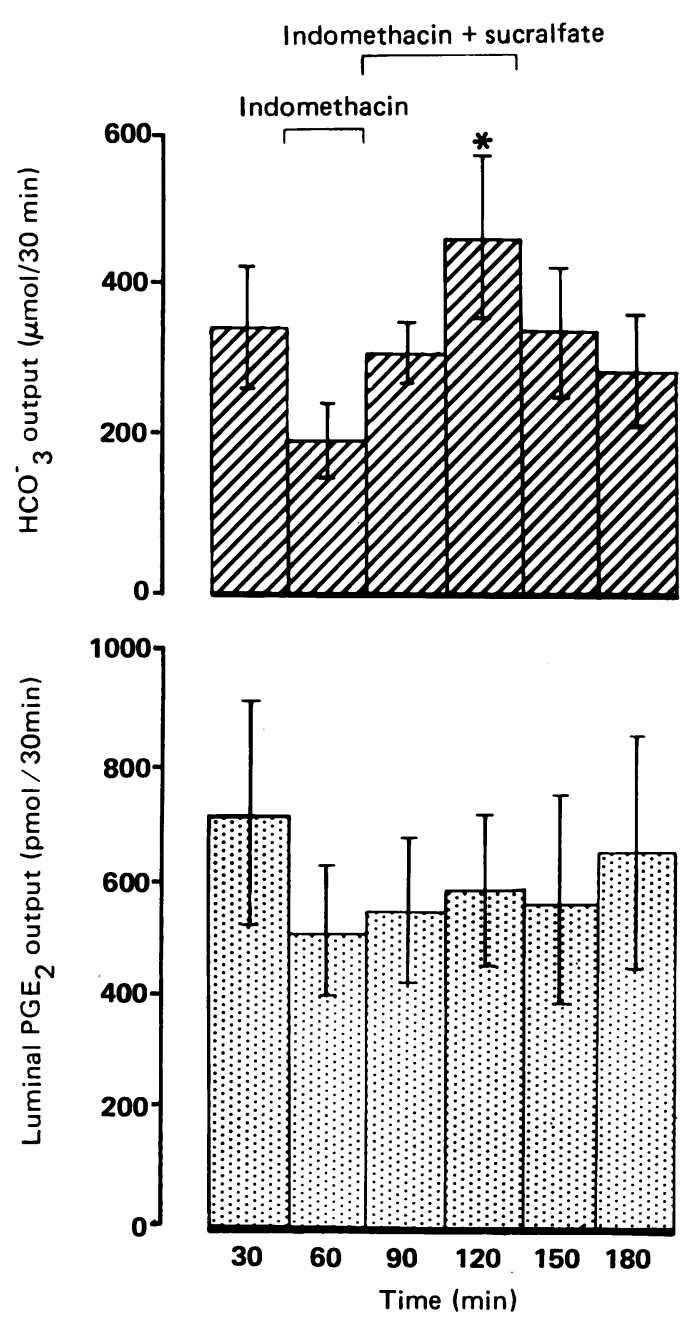

Figure 5: Effect of indomethacin and sucralfate on human gastric bicarbonate output (corrected for duodenogastric reflux) and luminal $P G E_{2}$ output (mean $(S E), n=6,{ }^{\star} p<0.01$ compared with immediately before adding sucralfate).

carbonate secretion or luminal $\mathrm{PGE}_{2}$ output in therapeutically relevant doses. These findings are at variance with a previous study in which stimulation of bicarbonate secretion was observed in man and dogs with similar concentrations of bismuth subcitrate. ${ }^{24}$ Stimulation of bicarbonate secretion by colloidal bismuth subcitrate has also been reported in studies on isolated amphibian gastric and duodenal mucosae by a mechanism independent of the local generation and release of prostaglandins. ${ }^{25}$ While our present study provides a clear demonstration that colloidal bismuth subcitrate has no effect on gastroduodenal bicarbonate secretion, the overall data from in vivo studies is conflicting.

In contrast with findings with colloidal bismuth subcitrate, therapeutic doses of sucralfate stimulated both human gastric and rat duodenal alkalinisation. In the human stomach there was a delayed rise in luminal $\mathrm{PGE}_{2}$ output. The temporal dissociation between stimulation of gastric luminal alkalinisation and increased lumina $\mathrm{PGE}_{2}$ output suggests that the two phenomena may not be linked, particularly as only the bicarbonate increase was coupled to volume flow. This is reinforced by the finding that pretreatment with the cyclooxygenase inhibitor indomethacin failed to prevent stimulation of bicarbonate secretion by sucralfate although stimulation of luminal $\mathrm{PGE}_{2}$ output was blocked. These observations support earlier in vitro experiments which showed that sucralfate induced alkali secretion was not inhibited by indomethacin pretreatment of amphibian gastric mucosa. ${ }^{14} \mathrm{~A}$ similar finding has been reported in respect of stimulation of mucus production by sucralfate. ${ }^{15}$

It is possible that sucralfate acts on the (prostaglandin-independent) $\quad \mathrm{Cl}^{-} / \mathrm{HCO}_{3}^{-}$exchange component of duodenal alkali secretion. This contention is reinforced by the fact that sucralfate stimulates alkali secretion in the stomach where anion exchange is thought to be the major mechanism of $\mathrm{HCO}_{3}{ }^{-}$transport. ${ }^{26}$ If, in the group of rats with high basal alkali secretion, $\mathrm{Cl}^{-} / \mathrm{HCO}_{3}{ }^{-}$exchange is operating maximally then an agent stimulating such exchange would be expected to show little or no effect on bicarbonate output whereas an agent stimulating electrogenic secretion such as $\mathrm{PGE}_{2}$ would remain effective. Such an explanation is consistant with our results which show that high basal secretion in the duodenum is associated with a response to $\mathrm{PGE}_{2}$ but not sucralfate while low basal secreting preparations responded to both sucralfate and $\mathrm{PGE}_{2}$.

These observations raise the intriguing possibility that sucralfate may act in three separate ways. First, by adhering to ulcerated mucosa it may produce a physical barrier to luminal acid and pepsin. Second, stimulation of endogenous prostanoid metabolism may enhance endogenous protective mechanisms that influence both ulcer healing and mucosal protection. Finally, sucralfate may directly stimulate the production of mucus gel and transport of bicarbonate by surface epithelial cells, possibly by a local irritant reaction. ${ }^{27}$ The latter effects would seem unlikely to play a role in ulcer healing but may be important in preventing damage to the intact epithelium.

It is possible that different components of sucralfate are responsible for these various actions. For example, sucrose may contribute to the ability of the complex to adhere to the mucosa and thus form a physical barrier, while aluminium can directly stimulate bicarbonate secretion. ${ }^{1+}$ Further, the protective action of sucralfate on oesophageal mucosa has been proposed to result from the presence of sulphate. ${ }^{28}$ It thus seems likely that the protective action of sucralfate is multifactorial with different components activating various mechanisms of gastroduodenal mucosal defence.

Both sucralfate and colloidal bismuth subcitrate $\left(\mathrm{De}-\mathrm{Nol}^{\circledR}\right)$ are primarily ulcer healing agents. Stimulation of bicarbonate secretion by sucralfate would be expected to enhance preepithelial acid disposal in the stomach and duodenum. In theory, such a property could prevent ulcer recurrence after initial healing, aleviate NSAID induced gastric damage, and reduce stress ulceration in severely ill patients. It is difficult to envisage, however, what role this would have in accelerating chronic peptic ulcer healing. Indeed, the absence of a viable epithelium in the region of an ulcer implies that the diseased mucosa would be unable to respond to stimulants of bicarbonate secretion. Thus we 
suspect increased rates of alkalinisation may be of little relevance to the chronic ulcer healing actions of sucralfate or colloidal bismuth subcitrate in man.

The authors are grateful to the Department of Medical Illustration, Hope Hospital for preparing the Figures. Dr Shorrock is British Society of Gastroenterology Research Fellow. Mr Hunter was a SERC (CASE) student. Expert technical assistance wa provided by Linda Gibbons, Susan Hampson and Angela Stanier.

1 Konturek SJ, Radecki T, Piastucki I, Drozdowicz D. Advances in the understanding of the mechanism of cvtoprotecvances in the understanding of the mechanism of cytoprotec-
tive action by colloidal bismuth subcitrate. Scand f Gastrotive action by colloidal bismuth subc

enterol 1986; 21 [suppl 122]: 6-10.
2 Hall DWR, Van Den Hoven WE. Gastric mucosal protection and prostaglandin $\mathrm{E}_{2}$ generation in rats by colloidal bismuth subcitrate. Arch Intern Pharmacodyn Therap 1987; 286: 308-19.

3 Hollander D, Tarnawski A, Krauser WJ, Gergeley H. Protec tive effect of sucralfate against alcohol-induced gastric mucosal injury in the rat. Gastroenterologv $1985 ; 88$ : 366-74

4 Hollander D. Efficacy of sucralfate for duodenal ulcers: a multicenter double

5 Kagevi I, Anker-Hanson O, Carling L, et al. Swedish Multicenter study on prepyloric and gastric ulcer. Scand $\mathcal{F}$ Gastroenterol 1987;22:67-76.

6 Tytgat GNJ, Rauws E, Langenberg W. The role of colloidal bismuth subcitrate in gastric ulcer and gastritis. Scand $\mathcal{Y}$ bismuth subcitrate in gastric ulcer and
Gastroenterol 1986; 21 [suppl 122]: 22-9.

7 Kang JY, Piper DW. Cimetidine and colloidal bismuth in treatment of chronic duodenal ulcer. Comparison of initia healing and recurrence after healing. Digestion 1982; 23: $73-8$.

8 Okabe S, Takeuchi K, Kunimi H, Kanno M, Kawashima M. Effects of the anti-ulcer drug, sucralfate (a basic aluminium salt of sulfated disaccharide, on experimental gastric lesions and gastric secretion in rats. Dig Dis Sci 1983;28: 1034-42.

9 Wieriks J, Hespe W, Jaitly KD, Koekkoek PH, Lavy UI. Pharmacological properties of colloidal bismuth subcitrate CBS, DE-NOL. Scand F Gastroenterol 1982; 17 [suppl 80]: $11-6$.

10 Nakazawa S, Nagashima R, Samloff IM. Selective binding of sucralfate to gastric ulcers in man. Dig Dis Sci 1981; 26: 297300

11 Samloff IM, O'Dell C. Inhibition of peptic activity by sucralfate. Am $\mathcal{7}$ Med 1985; 79 [suppl 2C]: 15-8.

12 Caspary WF, Graf S. Binding of bile acids by sucralfate and cholestyramine. In: Caspary WF, ed. Sucralfate. A new therapeutic concept. Baltimore: Urban and Schwartzenberg, 1981: 32-8.

13 Hollander D, Tarnawski A, Gergeley H, Zipser RD. Sucral- fate protection of the gastric mucosa against ethanol induced injury: a prostaglandin mediated process? Scand 7 Gastroenterol 1984; 19 [suppl 10]: 97-102.

14 Crampton JR, Gibbons IC, Rees WDW. Stimulation of amphibian gastroduodenal bicarbonate secretion by sucralfate and aluminium: role of local prostaglandin metabolism fate and aluminium:

15 Shea-Donohue T, Steel L, Montcalm E, Dubois A. Gastric protection by sucralfate: Role of mucus and prostaglandins Gastroenterologv. 1986; 91: 660-6.

16 Coleman JC, Lac\% JP, Brown RK, Drees DT. Effects of Sucralfate or mild irritants on experimental gastritis and prostaglandin production. Am $\mathcal{F}$ Med $1987 ; 83$ [suppl 3B] $24-30$.

17 Konturek SJ, Radecki T, Piastucki I, Brzozowski T, Drozdowicz D. Gastrocytoprotection by colloidal bismuth subcitrate (De-Nol) and sucralfate. Role of endogenous prostaglandins. Gut 1987; 28: 201-5

18 Martin DF, Hollanders D, May SJ, Ravenscroft MM Tweedle DEF, Miller JP. Difference in relapse rates of duodenal ulcer after healing with cimetidine or tripotassium dicitrato bismuthate. Lancet 1981; i: 7-10.

19 Hamilton I, O'Connors HJ, Wood HC, Bradbury I, Axon A Healing and recurrence of duodenal ulcer after treatment with tripotassium dicitrato bismuthate (TDB) tablets or cimetidine. Gut 1986; 27 : 106-10.

20 Dobrilla G, Vallaperta $P$, Amplatz $S$. Influence of ulcer healing agents on ulcer relapse after discontinuation of acute treatment: a pooled estimate of controlled clinical trials. $G u$ 1988; 29: 181-7.

21 Marshall BJ, Warren JR. Unidentified curved bacilli in the stomach of patients with gastritis and peptic ulceration. Lancet 1984; i: $1311-4$.

22 Flemstrom G, Garner A, Nylander $O$, Hurst BC, Heylings JR Surface epithelial $\mathrm{HCO}_{3}$ transport by mammalian duodenum in vivo. Am $\mathcal{f}$ Physiol 1982; 243 (Gastrointest Liver Physiol 6): 348-58.

23 Rees WDW, Botham D, Turnberg LA. A demonstration of bicarbonate production by the normal human stomach in vivo. Dig Dis Sci 1982; 27:961-6.

24 Konturek SJ, Bilski J, Kwiecien N, Obtulowic, W, Koop B Oleksy J. De-Nol stimulates gastric and duodenal alkalin secretion through prostaglandin dependent mechanism. (ivi 1987; 28: 1557-63.

25 Shorrock CJ, Crampton JR, Gibbons LC, Rees WDW. The effect of bismuth subcitrate on amphibian gastroduodenal bicarbonate secretion. Gut. (In press).

26 Flemstrom G, Garner A. Gastroduodenal $\mathrm{HCO}_{3}$ transport characteristics and proposed role in acidity regulation and mucosal protection. Am $\mathcal{f}$ Phvsiol 1982; 242: 183-93.

27 Garner A. Enhancing mucosal defense and repair mechanisms. In: Rees WDW, ed. Advances in peptic ulcer pathogenesis. Lancaster: $M T$

28 Orlando RC, Turjman NA, Tobey NA, Schreiner VJ, Powell DW. Mucosal protection by sucralfate and its components in acid exposed rabbit oesophagus. Gastroenterology 1987; 93 352-61. 